Review article

UDK: 378.6:65.012

Date of article receipt to the Editorial Board: April 13th, 2018.

Date of article submission to review: April 17th, 2018.

Date of paper acceptance for publication: June 5th, 2018.

\author{
Verica Babić, Ph.D* \\ Slađana Savović, Ph.D. **
}

\title{
UNIVERSITY CHARACTERISTICS AS THE SUCCESS FACTOR OF ACADEMIC SPIN-OFFS
}

\author{
KARAKTERISTIKE SVEUČILIŠTA KAO FAKTOR USPJEHA \\ AKADEMSKIH SPIN-OFF PODUHVATA
}

\begin{abstract}
The complexity of knowledge-based society is constantly adding new challenges for higher education institutions. Entrepreneurial university model is developed in such a way that it incorporates the additional role of the commercialization of knowledge and active contribution to the development of private enterprises in the local and regional economy. The main objective of the paper is to explore the characteristics of university which support entrepreneurial activities and facilitate the generation and exploitation of knowledge and technology. The main research question is how the university can become an incentive factor for the development and success of academic spin-off ventures? The results of the research have shown that the characteristics of the social and institutional environment influence the development and success of academic spin-off ventures by developing various mechanisms that encourage innovation and entrepreneurship. In addition, the research has shown that the university, by strengthening the culture of academic entrepreneurship as well as, by establishing cooperation with industry and public institutions on all levels, encourages the development of academic spin-off ventures. In the concluding observations, we emphasized the importance of further research in the field of higher education institutions, in order to provide additional contribution to the literature focused on academic entrepreneurship, as well as to provide practical recommendations for improving the success of academic spin-offs.
\end{abstract}

KEY WORDS: academic spin-off, entrepreneurial university, entrepreneurial learning, knowledge transfer.

Verica Babić, Ph.D., Full Professor, Faculty of Economics, University of Kragujevac, Dj. Pucara Starog 3 , 34000 Kragujevac, Serbia, vbabic@kg.ac.rs.

** Slađana Savović, Ph.D., Assistant Professor, Faculty of Economics, University of Kragujevac, Dj. Pucara Starog 3, 34000 Kragujevac, Serbia, ssladjana@kg.ac.rs. 
SAŽETAK: Složenost društva zasnovanog na znanju neprekidno stvara nove izazove institucijama u visokom obrazovanju. Model poduzetničkog sveučilišta razvijen je na način da inkorporira dodatnu ulogu komercijalizacije znanja i aktivni doprinos razvoju privatnih kompanija u lokalnom i regionalnom okruženju. Osnovni cilj rada je istražiti karakteristike sveučilišta koje podupiru poduzetničke aktivnosti i olakšavaju stvaranje i iskorištavanje znanja i tehnologije. Glavno istraživačko pitanje je kako sveučilište može postati poticajni faktor razvoja i uspjeha sveučilišnih spin-off poduhvata? Rezultati istraživanja su pokazali da karakteristike društvenog i institucionalnog okruženja utječu na razvoj i uspjeh sveučilišnih spin-off poduhvata kroz razvoj različitih mehanizama koji potiču inovativnost i poduzetništvo. Dodatno, istraživanje je pokazalo da sveučilište jačanjem kulture akademskog poduzetništva, kao i uspostavljanjem suradnje s industrijom i lokalnim/regionalnim i državnim institucijama potiče razvoj sveučilišnih spin-off poduhvata. U zaključnim razmatranjima istaknut je značaj daljih istraživanja u području visokoobrazovnih institucija kako bi se pružio doprinos literaturi iz područja akademskog poduzetništva i pružile praktične preporuke za unaprjeđenje uspjeha akademskih spin-off poduhvata.

KLJUČNE RIJEČI: akademski spin-off poduhvati, poduzetničko sveučilište, poduzetničko učenje, transfer znanja.

\section{INTRODUCTION}

During the past two decades, the area of academic entrepreneurship becomes visible, and universities move more and more from the traditional educational and research role to more complex entrepreneurial model of universities by incorporating additional role that refers to the transfer and commercialization of generated knowledge (Pattnaik and Pandey, 2014). It is about so called "third mission" of universities that should provide direct contribution to the development of wider social and economic community. In that sense, the modernization of universities means a series of processes directed towards the transfer of knowledge and technology from universities to companies and the market (Visintin and Pittino, 2014). One of the ways of commercialization of knowledge is forming academic spin-off ventures that are initialized in university surrounding so that the intellectual property, created within academic institution, could be used for the development of products and services with which it would appear on the market. The importance of creating academic spin-offs is recognized in the world to a great extent, especially in developed countries. Following the experience of developed countries, transition economies, including the Republic of Serbia, realize that the encouragement of creating spin-off ventures, for the purpose of commercialization of university research is of great importance. Since the creation of academic spin-offs is still at the very beginning, the mentioned problem is not researched enough which indicates the importance of the study of academic spin-offs in order to provide the contribution to the literature in the area of academic entrepreneurship and provide better understanding how universities can develop their entrepreneurial abilities and encourage the creation of new research-based projects.

Basic aim of the paper is to research the characteristics of universities that support entrepreneurial activities and facilitate generating and exploitation of knowledge and technology. Out of the basic aim, the specific aims are derived: the overview of new entrepre- 
neurial role of universities related to the transfer and commercialization of knowledge via creating academic spin-off ventures, the analysis of different mechanisms of support in creating spin-off ventures and observing the possibilities of forming spin-off ventures at the University in Kragujevac.

In the process of research, the qualitative methodology was applied, based on the collection of information from different sources and their interpretation, as well as in the descriptive analysis of research problem. Having in mind the fact that the area of academic entrepreneurship represents insufficiently researched area, theoretical approach to the problem is combined with empirical approach. In the paper the case study method is used that is suitable for the study of complex problems that demand the examination in real conditions. In accordance with the chosen subject and the aims of research in the paper is primarily explained entrepreneurial university model and indicated that the creation of academic spin-off ventures represents an important mechanism of commercialization of research results. On the basis of literature overview in the area of academic entrepreneurship the factors that determine the success of academic spin-offs are being analyzed. Specifically, the characteristics of social and institutional surrounding are being analyzed, and special attention is paid to the analysis of mechanisms of university support to the development and success of academic spin-offs. Finally, the different mechanisms of support to the forming of spin-offs at the University of Kragujevac were being analyzed.

\section{ENTREPRENEURIAL UNIVERSITY MODEL AND THE CREATION OF ACADEMIC SPIN-OFFS}

In the economy based on knowledge, the knowledge represents the imperative for the development of sustainable competition advantage. Hence, managing knowledge and its commercialization become main aims and driving force of the $21^{\text {st }}$ century economy. The role of universities has always been that through the education and research they contribute to the creation of richness and economic development, but with the economy of knowledge it becomes even more significant, since it is expected from the academic research to be included in the economic cycles of innovation and growth (Dooley and Kirk, 2007).

Universities become the place at which the companies meet, cooperate and exchange ideas, which results in collective regional learning process and dissemination of knowledge. By explaining new role of universities, Etzkowitz and Leydesdorff (2000) make a difference between the two types of universities Mod1 and Mod 2 depending on the manner of organizing and the use of results of scientific and research process. For Mod 1 it is characteristic that the research develops within the autonomous scientific areas and that is lead by the interests of academic community, while the research according to the second model - Mod2, is interdisciplinary, multidisciplinary and transdisciplinary, and it develops in the context of the possibility of application, it is heterogeneous and directed towards the commercialization of results. More advanced variant Mod2 is „Triple Helix“ concept according to which universities have special role in the encouragement of innovation through specific relations and interaction between previously separated segments - universities, industry and state. Hence the governments in technologically advanced and developed countries show growing interest for academic entrepreneurship and support the development of entre- 
preneurial university through the policies that stimulate the cooperation of universities and economy. Academic entrepreneurship is the process through which individuals or groups, whose work is connected to the work of universities or research centers, use the knowledge developed during their research in order to found a company, i.e. academic spin-offs (Miranda et al., 2017).

The creation of academic spin-offs represents the desirable mechanism for the transfer of knowledge and technologies from universities to private sector for the purpose of commercialization (Czarnitzki, et al., 2013). It is about the specific group of start-up companies whose aim is the use of technological knowledge originated within the university for the development of products and services (Bigliardi et al., 2013). Bigliardi et al. (2013) emphasizing that it is about the "companies that emerge from universities, where the group of researchers forms an entrepreneurial unit" in order to use the part of intellectual property created within academic institution. In the protection of intellectual property the patents, copyright and other legal mechanisms of protection can be used. Teaching staff of a faculty and/or students can be included in the formation of academic spin-offs, and the leader of spin-off venture can be entrepreneur that does not have to necessarily be from university.

The promotion of academic entrepreneurial activities and the creation of spin-offs is very complex. By studying the development of academic spin-offs the authors have identified different phases of development (Ndonzuau et al., 2002; Vohora et al., 2004; Pattnaik and Pandey, 2014). Ndonzuau et al. (2002) have presented multiphase conceptual model of formation of spin-offs (Figure 1): generating of business idea (phase 1), finalization of the new venture project on the basis of idea (phase 2), startup of spin-off company on the basis of project (phase 3 ) and the creation of values by spin-off company (phase 4).

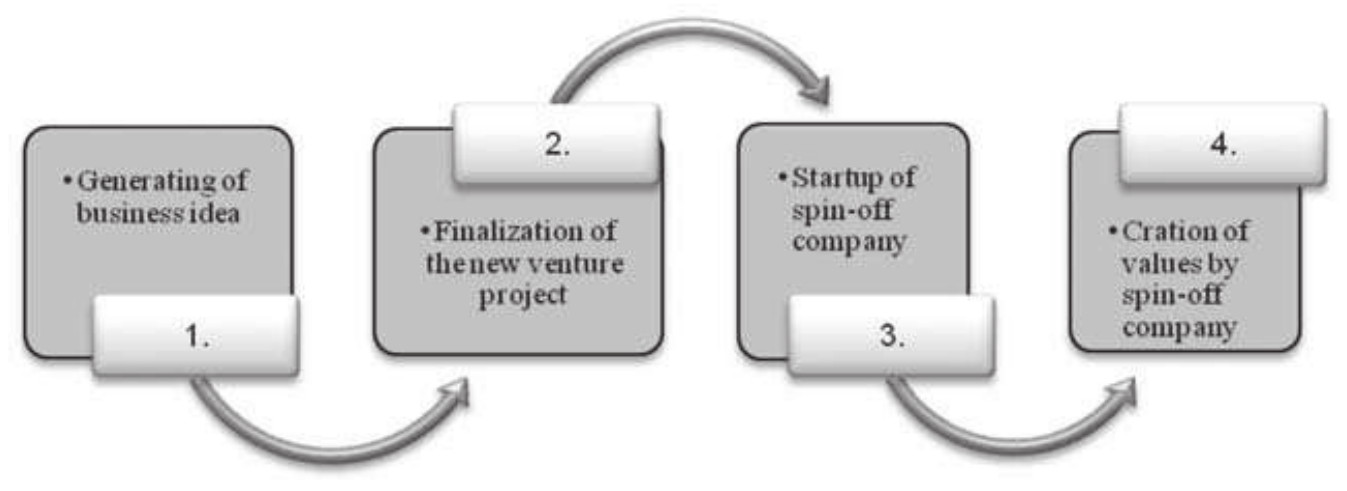

Figure 1. Phases of development of academis spin-offs

Source: Ndonzuau at al. (2002)

The purpose of the first phase is to create business ideas, suggestions and proposals, within scientific community, for commercial use. Commercial exploitation of knowledge demands getting closer of the two opposite science concepts. Namely, it is necessary to get closer ,scientific"conception, that observes science as the purpose by itself, and "economic" conception, that observes science as the way of realizing other purposes. Created ideas within the first phase usually consist of scientific and technical elements, while their earning potential is still unknown. In this phase, there is only a feeling or rough assumption that 
research results have promising economic potential. This assumption has to be confirmed within business project. Hence, the purpose of the second phase is transforming bad structured idea into a coherent and structural venture of project creation that should specify the two important issues: protection and development of idea. This step can demand significant investments and clearly marks the first big step from the research to business sphere. The third phase deals with the creation of a new company that will be focused on the exploitation of possibilities which will be managed by a professional team and which is supported by available resources. In the fourth phase it comes to the consolidation and strengthening of economic value created by company. This phase encompasses the creation of value by spin-off company by generating for the local economy both material benefits (business, investments, taxes) and non-material benefits (entrepreneurial dynamism, forming of centers of excellence).

The importance of forming academic spin-off ventures is reflected in the fact that these ventures perform the whole series of different functions including the performance of technology transfers and commercialization of research, the increase of the reputation of faculties and universities, the increase of possibilities of employment of scientific workers and students, the realization of direct income for universities. Gabrelsson et al. (2006) emphasize that academic spin-offs offer the incentive for the creation of greater value that can be returned to academic institution or researcher. Apart from that, successful new ventures based on university generated knowledge affect the strengthening of the relation with local community. New companies that are separated and become independent from universities strive to locate themselves near parent university and economic benefit that is created from them (within opening of new work places and taxation of incomes) is accumulated locally, while the technology transfer towards bigger corporation means the possibility of realizing the benefit outside direct region (Gabrelsson et al. 2006). Academic spin-offs become more recognizable as possible initiators of regional and national competence in global surrounding, having in mind their potential in the increase of economic activity (Visintin and Pittino, 2014).

\section{THE FACTORS THAT DETERMINE THE SUCCESS OF ACADEMIC SPIN-OFFS}

The review of literature on academic spin-offs (Shane, 2004; Smilor and Matthews, 2004; O’Shea et al., 2005; Clarysse et al., 2011; Bigliardi et al., 2013, Muscio et al., 2016) reveals different factors that determine the success of these research-based ventures. O'Shea et al. (2005) discovered that the success of academic spin-offs is affected by the quality of universities, commercial ability of universities and the nature of financing by universities. The same authors identified other factors as well, that are connected to the surrounding, and that determine the success of academic spin-offs: the speed and availability of risky capital, regional infrastructure, the policy of the protection of intellectual property at the university and characteristics of the branch. Smilor and Matthews (2004) show that the support that university provides to the spin-off companies can increase the chances of success and hence they suggest the following important factors: financial support of parent organization, competent staff, transparency, the access to the qualified entrepreneurial skills. Clarysse et al. 
(2011) emphasize the significance of technological resources in determining performances of academic spin-offs, that relate to: the degree of innovation, the phase of technological development, the protection of intellectual property and the scope of the very technology/ product. Shane (2004) emphasizes that certain universities generate bigger number of spinoff activities in relation to others, and three main reasons are: the differences in university policies, the differences in the existence of university offices for licensing and the differences in other characteristics of university. Muscio et al. (2016) emphasize that the policies and the rules of university can have key role in the creation of academic spin-offs. On the basis of the review of literature on the factors that determine the success of academic spinoffs it can be concluded that the characteristics of social and institutional surrounding in the combination with the characteristics of university affect the development and success of academic spin-offs by developing of different mechanisms that encourage innovation and entrepreneurship.

The founders of academic spin-offs are faced with great challenges regarding the need of providing the sources of financing in the early phase of venture occurrence. In the initial phase the first financial resources necessary for initiating new venture are provided by the founders themselves from their personal savings, micro investments received by their families and friends. Certain financial means can be provided by university. However, in later phase, the successful commercialization of innovation or technological inventions demands additional resources for the continuation of I\&R, marketing, production and management. One of the solutions is finding additional support from the owner of risky capital (venture capitalists) (Gabrelsson et al., 2006). The owners of the risky capital buy the share in spin-off and start-up companies that have high potential of growth for the purpose of realization of high rates of incomes after certain time period. The studies have shown that bigger share of financing by economy (O'Shea et al., 2005) and previous connection to the owners of risky capital (Shane and Stuart, 2002) positively affect the performances of academic spin-offs. Risky capital has a key role, both in direct financial support that provides capital investments, and in additional support that is typically related to the early phase of investment.

For the purpose of mitigation of financial limitations, financial support can be offered through specific programs that have for their purpose the encouragement of creation of new ventures in highly technological sectors. Science, research and technological development are the priorities of policies and activities of European Union. In that sense European Union encourages universities, science and research institutes, academic spin-offs in their research and technological and developmental efforts. Horizon 2020 is a new program of European Union for the research and innovations for the period 2014-2020 and unifies Seventh framework program (FP7), the part of the Program for competitiveness and innovations (CIP) and European institute for innovations and technology (EIT).

Local context can develop specific services of support to entrepreneurship that are directly focused on providing help to new ventures in early phase of development. The examples of such services can be found in different initiatives that are launched by public agencies and local self-governments, and that are ranked from the possibility of training, obtaining small loans and direct services to physical infrastructure, such as public incubators and scientific and technological parks (Fini et al., 2011). 


\section{MECHANISMS OF UNIVERSITY SUPPORT TO THE DEVELOPMENT OF ACADEMIC SPIN-OFFS}

University competences that facilitate the creation of academic spin-offs refer to the ability of university to initiate and promote the process of creation of ventures. Undoubtedly, these abilities are the most important during the earliest phases of entrepreneurial process, when universities serve as incubators for emerging spin-off venture. When new company becomes independent entity, university is one of the stakeholders that affect its further growth and development. Hence, the key element of university abilities in encouragement of university spin-offs relates to the ability of university to enable the startup of entrepreneurial activities (Rasmussen and Borch, 2010).

Van Burg et al. (2008) emphasize five key areas for designing and implementation of academic spin-offs. The first area includes the need of the creation of conscience at the level of entire university on entrepreneurial opportunities, by stimulation of atmosphere for the development of entrepreneurial ideas. The second area refers to providing the support to start-up teams in combining and acquiring suitable mixes of entrepreneurial knowledge and skills. The third area is connected to the development of professional and social networks in order to provide easier access to the necessary resources. The fourth area demands loud and precise formulation of the rules and procedures for academic spin-offs by which fair treatment of interested parties will be provided, the conflict of interest between commercial and academic activities will be prevented and the issue of risk taking of failure will be regulated. The fifth area includes the development of organization culture that empowers entrepreneurship through the system of values and norms by which entrepreneurial behavior is being stimulated (Van Burg et al. 2008).

In order to stimulate the atmosphere for the development of entrepreneurial ideas it is necessary to emphasize the importance of entrepreneurial learning that should be available to the entire academic community and all students through the integration into the programs of high education. Apart from that, the university should provide the support to the researchers when starting up academic spin-offs. For example, although technical aspects and commercial potential of innovations can be clearly identified, the development of the draft proposal of the project and business plan can be the activity that is not known to the researchers-inventors (Muscio et al. 2016). The lack of necessary abilities can be observed as the obstacle for spin-off activities. The mechanisms of university support in this context refer to the existence of the centers for technology transfer (Shane, 2004, Siegel et al., 2007, Fini et al., 2011) in which highly professional individuals work, and who possess necessary knowledge, abilities and skills for the assessment of market, writing of business plans, attracting of risky capital, etc. The existence of such kind of support by university increases the probability of success of academic spin-offs. Apart from that, it is necessary to develop and organize special training programs for the purpose of development of entrepreneurial competences with researchers.

The university policy that leads to the fact that some university generate bigger number of spin-offs in relation to others also refers to the possibility of the use of university resources for the development of companies (Shane, 2004). Apart from non-material resources, both material and financial resources are necessary to all start-up companies. Certain universities allow academic entrepreneurs the access to university research-developmental 
laboratories, scientific institutions and academic incubators. These possibilities can be especially relevant for spin-offs that cannot afford initial investment necessary for the supply of capital equipment (Fini et al., 2011). Hence, university incubators that support early startup phase by providing services and objects (e.g. the access and use of expensive instruments, laboratory equipment and the like) in order to support the production to commercial distribution, can be very efficient way of encouragement of academic spin-offs. Financial resources can be also provided by university by forming internal funds at the university that will provide support to the development of spin-offs. Apart from the use of support network at the university, it is necessary to develop professional and social networks with the institutions in surrounding that can provide necessary resources and services.

Universities should have clearly and precisely formulated rules and procedures for forming academic spin-offs. The rules on the conflict of interest between universities and spin-offs play significant role. Well defined rules on the conflict of interest, and especially on the compatibility of such activity with multiple roles of researchers in fulfilling university missions, represents one of the significant factors of the success of academic spin-offs. One of the policies that affect the rate of academic spin-off activities is exclusive licensing. Issuing of exclusive licenses encourages spin-off activities for several reasons. Entrepreneurs are not ready to found companies and take risks of development of new technology, and investors are not ready to support them financially, until they are certain that they have exclusive right over those technologies. The readiness of universities to take participation in the ownership in exchange for the payment of patents and other expenses facilitates the formation of spin-offs.

Building of entrepreneurial culture at universities demands great effort and long-term commitment of all included stakeholders. Traditionally, at universities there is a strong influence of ,science" paradigm according to which as the only purpose of academic research the increase and improvement of human knowledge is emphasized, regardless its practical application. This paradigm has contributed to the value system that is deeply rooted in academic culture and that is opposite to the valorization of research via spin-offs. Within such value system it is difficult to change the focus of the researchers that are primarily oriented towards publishing of scientific works, and not towards entrepreneurial activities. Hence, in order to develop organizational culture that empowers entrepreneurship, it is necessary to establish standards and incentives that stimulate academic staff to participate in entrepreneurial activities. One aspect of encouragement is reflected in providing possibilities of part-time employment since many scientific workers do not want to permanently leave their positions at the universities for the purpose of employment within spin-off companies.

Breznitz et al. (2008) emphasize that the strategies have to be adjusted to the specific demands of spin-offs and institutions out of which they emerge, which means that contingency approach has to be used, and not universally valid one for all cases. The support to the development of spin-offs at universities depends on the basic dimensions of organizational structure: complexity, the degree of centralization and formalization. In the research that was conducted by Rasmussen et al. (2014) it is pointed to the influence of certain departments on the development of entrepreneurial competences. The role of the chiefs of departments and colleagues in certain scientific areas is emphasized, since the evaluation of performances, allocation of free resources, establishing of social networks and support to the research venture is taking place primarily at that level. Sometimes it can happen that 
in spite of well defined university strategy for the development of spin-offs, organizational structure represents the obstacle to the implementation of the strategy. In early phases of development it is necessary to provide the conditions for the development of entrepreneurial competences necessary for the transition from academic research results to identifying the potential for commercialization and founding of spin-offs. The decision that academic status should be amended or replaced by entrepreneurial one can be set back by insisting on the routine established by the tradition of department and declared inappropriate for elitist position of top researcher.

It can be concluded that university, in order to be incentive factor of development of spin-offs, has to replace traditional role with a new, entrepreneurial, that means defining entrepreneurial strategies as across-campus perspectives, networking at the local, regional, national and international level, the use of the examples of good practice of academic spin-offs and development of special training programs for the purpose of the development of entrepreneurial competences with researchers.

\section{CASE STUDY - MECHANISMS OF SUPPORT OF THE UNIVERSITY OF KRAGUJEVAC TO THE FORMING OF ACADEMIC SPIN-OFF}

University of Kragujevac consists of twelve faculties that have the status of legal entity and are dispersed at several locations in Central Serbia. At almost all faculties there are very strong research centers, institutes or laboratories in which scientific work is developed and significant scientific results are obtained. Pursuant to the need of university to, apart from traditional education and research role, incorporate additional role that refers to the transfer and commercialization of knowledge, at the University is recognized market potential of the Center for Pre-clinical Testing of Active Substances of the Faculty of natural sciences, of the University of Kragujevac. Hence the procedure of forming academic spin-offs was started, that would emerge by separation and independence of the Center as a special entity that would do business according to market principles. The Center is founded as special organizational unit in 2008 as a result of realization of three-year project EU: FP7 - Capacities, Research Potential, Centre for pre-clinical testing of active substances (CPCTAS, GA 206809). The laboratory for cell and molecular biology represents central and coordinating segment of Center activities. Basic activities of laboratory have for their purpose the study of the significance of physiological, genetic, molecular and biological and tumor markers in the assessment of the effects of active substances and predicting of pathological conditions of people. Market potential of Laboratory is reflected in the significance of services that are provided by it, and that can have commercial value. As the users of Laboratory services the research laboratories of similar character were recognized that realize their cooperation within scientific and research activity by participation in common research projects, or by providing services; pharmaceutical companies through the cooperation within scientific and research activity or by providing services of Laboratory; foreign partners can use the services within the existing capacities of laboratory and health institution.

For the purpose of building the institutional infrastructure at national level in previous ten years several important strategies and programs have been adopted by which innova- 
tion and entrepreneurship is supported. Strategy for development of education in Serbia to 2020 contains two chapters that refer to the third mission of university. For the purpose of defining and establishing measures for improvement of excellence in science and its focus on the research for the development of economy and society, the Strategy of scientific and technical development of the Republic of Serbia was adopted for the period from 2016 to 2020 - „The research for innovation“. One of the measures predicted by this strategy is the encouragement of founding companies based on scientific and research work, i.e. spin-off companies.

The Strategy for the support of development of small and medium-sized enterprises, entrepreneurship and competitiveness was also adopted for the period from 2015 to 2020, by which the policy of respecting and application of all documents that establish the policy of European Union in the area of entrepreneurship and competence is being continued. In the context of the third mission of university the most important aspects of the strategy refer to the improvements in the area of human resources and the support to the development of innovation. By the Law on Innovation Activity the issues of application of scientific knowledge, technical and technological knowledge, inventiveness and inventing in the function of creating new products and services are being regulated. The Law recognizes business and technological incubators, scientific and technological parks, centers for the transfer of technology as the organization for providing the support to the innovation activity.

For the purpose of stimulating academic entrepreneurship different mechanisms of support are developed at University. Observed by the areas that Van Burg et al (2008) quote, and that are of key significance for designing and implementation of academic spin-offs, firstly it is necessary to stimulate atmosphere for the development of entrepreneurship at University. University has created, by using the examples of good practice from certain faculties, institutional and organization assumptions for the development of entrepreneurial behavior. University of Kragujevac has especially developed good infrastructure for enhancement of innovation due to numerous international projects (,Modernization of WBC universities through strengthening of structures and services for knowledge transfer, research and innovation“, „Institutional framework for the development of third mission of universities in Serbia“, etc.).

The second area refers to providing support to start-up teams in the development of entrepreneurial skills. Employed in laboratory possess necessary scientific and practical knowledge for implementing all types of services that are offered within Laboratory, that are dedicated, motivated and with desire to make their venture alive and successful. However, at the very beginning, apart from the idea that the services provided by Laboratory can have market potential, clearly structured entrepreneurial strategy was missing. The analysis of market, competitors, the analysis of strengths and weaknesses of Laboratory, the possibilities and threats from the surroundings represented the unknown fact for the researchers. Apart from that, these researchers were missing necessary entrepreneurial skills and market orientation that were necessary for market commercialization of the services. Within the interdisciplinary project „Pre-clinical Testing of Bioactive Substances” and sub-project "Management and Marketing Research as Support to the Realization of the Interdisciplinary Projects" the cooperation with the researchers in the area of economy was predicted for the purpose of completing of knowledge and the creation of basis for outgrowth of the Center into spin-off venture. For the development of necessary entre- 
preneurial skills it is necessary to organize specialized training programs and additional improvements in this area.

The third area is connected to the development of professional and social networks in order to provide easier access to necessary resources. At the level of University different organizational units are formed that provide support to the transfer of knowledge and research: Center for scientific and research work SANU, Cooperative training center, The Office for international projects, Center for lifelong learning, Center for technology transfer, etc. $)^{1}$. One of the most significant mechanisms of the support of University of Kragujevac in forming academic spin-offs refers to founding of the Center for the transfer of technology which is, as organizational unit of University of Kragujevac, founded by the end of 2012 for the purpose of identification, legal protection and commercial use of intellectual goods. Basic aims and assignments of the Center are to improve the possibilities for the efficient and effective application of scientific and research results of University, encourage knowledge transfer between University and economy, and provide support to the placement of new technologies and innovations. The center formed in this way could not be supported financially through the calls of public competitions, since it did not have the status of a company. Pursuant to the Law on innovation activity the entry into the Register of innovation activity represents the condition for the access to the financing by budgetary funds. Hence in July 2017 the Center for the transfer of technology is registered as the society with limited responsibility and is entered as legal entity into the Register of innovation activity. Parallel with these processes, at the level of University the efforts of establishing cooperation with the industry and local/regional and state administration are made, so that business and innovative networks for better transfer of knowledge are built. In Kragujevac, as regional center, there are several institutions that support the development of entrepreneurship, the strengthening of innovative infrastructure and the cooperation of University with companies. For the purpose of better understanding the support mechanisms of University in the creation of spin-off ventures, especially regarding establishing the cooperation with surrounding institutions, graphic display of dynamic virtual network of University, industry and state administration will be used. (Figure 2).

The fourth area of significance for designing and implementation of academic spin-offs refers to clear and precise formulation of rules and procedures. Apart from founding the centers, the series of legal acts were also brought whose aim is the strengthening of legal mechanisms in the support of knowledge exchange, excellence in research and innovations. Especially important issue during the outgrowth of the Center in academic spin-off is the protection of intellectual property. In that sense in 2017 the Rulebook on managing intellectual property was adopted in order to provide help to the researchers regarding the assessment, recognition, registration, economy exploitation and the protection of intellectual property that emerges at the University of Kragujevac. 


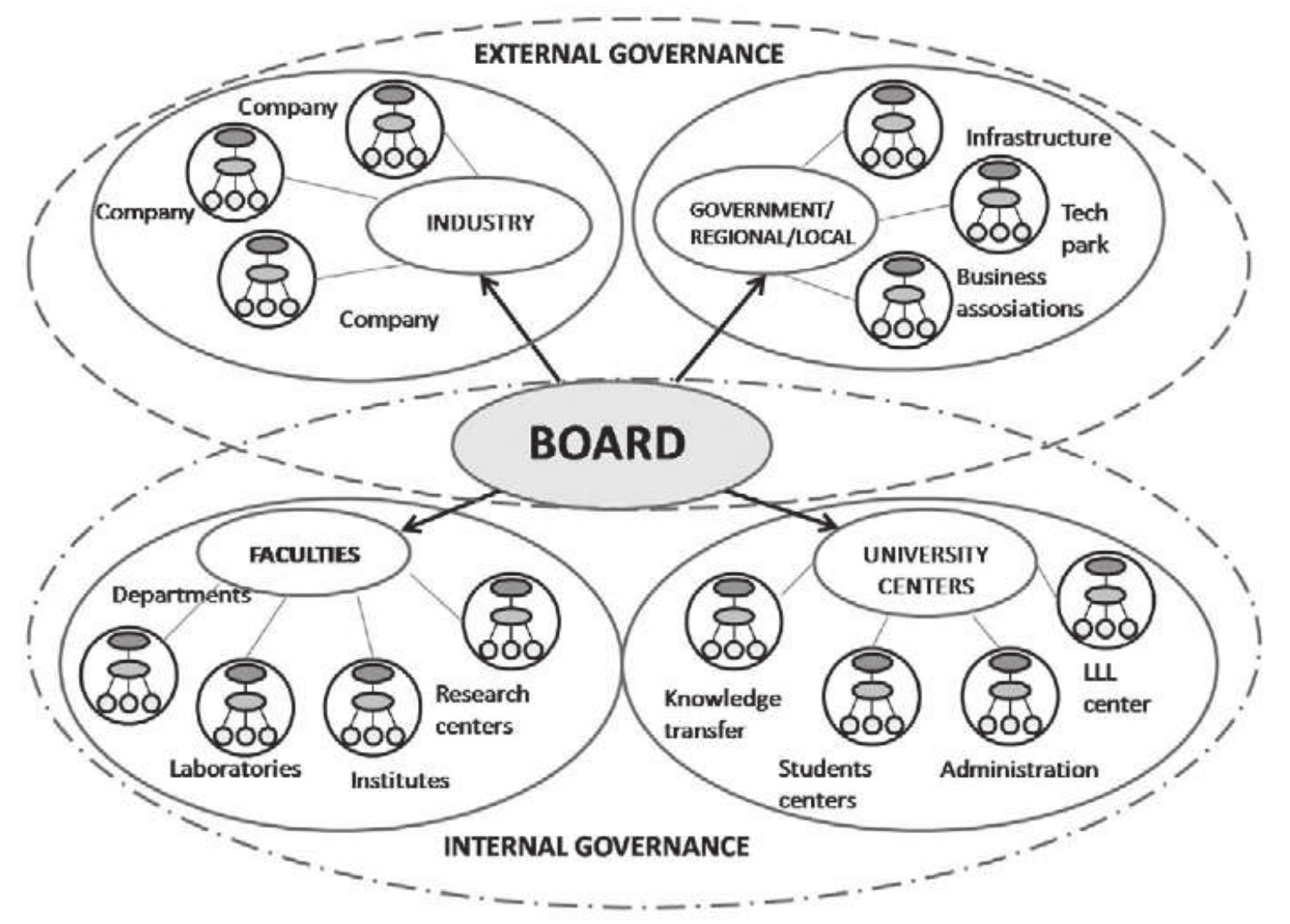

Figure 2. Dynamic virtual network of University, industry and state administration

Source: Autors

The building of organizational culture that empowers entrepreneurship represents one more key area for designing and implementation of academic spin-offs. Traditionally, at universities there is a strong influence of "scientific" paradigm according to which as the only purpose of academic research the increase and improvement of human knowledge is emphasized, regardless its practical application. This paradigm has contributed to the value system that is deeply rooted and which is the opposite of valorization of research via spin-off ventures. The University of Kragujevac made significant efforts to, by changing the system of values, beliefs and norms, implement new organizational culture that insists on the unity, community and bigger centralization, with the strengthening of institutional autonomy of university. In the following period there are intensive activities in promoting entrepreneurial culture upcoming, by application of functional and symbolic approach to shaping of organizational culture. Radical changes always carry great risk of disturbing one of the basic principles of effectiveness of organization, subordination of individual interest to general interest, due to which it is necessary to develop mechanisms of protection in a parallel way by which predatory appetites of individuals and departments would be prevented, and that encompass the application of classic organizational principles of establishing material and social order and reward system. 


\section{CONCLUSION}

Recently, universities shift from their traditional role of research, teaching and dissemination of knowledge towards more advanced role of creating academic spin-offs and promoting entrepreneurship. The creation of academic spin-offs is oriented in the direction of transfer and commercialization of university generated knowledge towards the market. The encouragement and creation of academic spin-offs, as well as their success are determined by different factors. The review of different empirical research indicates that the characteristics of social and institutional surrounding in the combination with the characteristics of university affect the development and success of academic spin-offs by developing different mechanisms of support to the development of innovation and entrepreneurship. In the Republic of Serbia the institutional framework for stimulation and encouragement of entrepreneurship at universities has been developed.

University of Kragujevac has the potential for providing support to entrepreneurship and stimulation of development of academic spin-offs. According to analyzed areas that are key for the development of academic spin-offs it can be concluded that there is a strategic orientation of awareness development at the level of entire university and all its members on entrepreneurial circumstances. Regarding the second area, that encompasses the support to start-up teams in acquiring entrepreneurial knowledge and skills, specialized programs of training and improvement in this area are missing. The third key area refers to the development of professional and social networks, and in that area the University succeeded in building the networks at local, regional, national and international level that are the basis of cooperation and easier access to the resources. In the fourth area clearly defining of rules and procedures are demanded in order to determine the place of spin-off ventures in the existing internal and external configuration of resources and the ways of their allocation, in order to prevent the conflict of interest and determine the boundaries of current and future organizational entities. One aspect of encouragement is reflected in the providing of possibilities of part-time employment, since many researchers do not want to permanently leave their positions at universities for the purpose of employment within spin-off companies. The fifth area encompasses the building of entrepreneurial culture and represents one of the most difficult assignments since it demands the change of paradigm of academic excellence into the paradigm of creating results that lead to the commercialization or socially useful application. The change of adopted systems of value, norms and patterns of behavior demands radical approach, because the resistances of dominant academic coalitions are destructive from the point of view of innovative leadership and spin-off ventures.

Since the creation of academic spin-offs in our conditions is still at the very beginning, the stated problems are not expressed enough, which implies the significance of further research in this area in order to provide the contribution to the literature in the area of academic entrepreneurship, define basic principles for the founding of academic spin-offs and provide practical recommendations for their implementation. 


\section{REFERENCES:}

Bigliardi, B, Galati, F., \& Verbano, C. (2013). Evaluating Performance of University SpinOff Comapanies: Lessons from Italy. Journal of Technology Management \& Innovation, 8(2), 178-188.

Breznitz, S., O’Shea, R., \& Allen, T.(2008). University commercialization strategies in the development of regional bioclusters. The Journal of Product Innovation Management, 25(2), 129-142.

Clarysse, B., Tartari, V., \& Salter, A., (2011). The impact of entrepreneurial capacity, experience and organizational support on academic entrepreneurship. Research Policy, 40, 1084-1093.

Czarnitzki, D., Rammer, C., \&Toole A. (2013). Unversity Spinoffs and the „Performance Premium“, Discussion Paper No. 13-004, Centre for European Economic Research, Retrieved Septrember 10, 2017, from http://ftp.zew.de/pub/zew-docs/dp/dp13004.pdf

Dooley, L., \& Kirk, D. (2007). University-industry collaboration: Grafting the entrepreneurial paradigm onto academic structures. European Journal of Innovation Management, 10(3), 316-332

Etzkowitz, H., \& Leydesdorff, L. (2000). The Dynamics of Innovation: From National Systems and 'Mode 2' to a Triple Helix of University-Industry-Government Relations. Research Policy, 29(2), 109-123.

Fini, R., Grimaldi, R., Santoni, S., \& Sobrero, M. (2011). Complements or substitutes? The role of universities and local context in supporting the creation of academic spin-offs. Research Policy, 40, 1113-1127.

Gabrelsson, J. ,Landström, H., \& Brunsnes, T. (2006). A Knowledge-based Categorization of Research-based Spin-off Creation, Paper no. 2006/06, Centre for Innovation, Research and Competence in the Learning Economy (CIRCLE), Lund University.

Miranda, F., Chamorro-Mera, A., \& Rubio, S. (2017). Academic entrepreneurship in Spanish universities: An analysis of the determinants of entrepreneurial intention. European Research on Management and Business Economics, 23(2), 113-122

Muscio, A., Quaglione, D., \& Ramaciotti, L. (2016). The effects of university rules on spinoff creation: The case of academia in Italy. Research Policy, 45, 1386-1396.

Ndonzuau, N., Pirnay F., \& Surlemont B. (2002). A stage model of academic spin-off creation. Technovation, 22, 281-289.

O'Shea, R., Allen,T., Chevalier, A., \& Roche, F. (2005). Entrepreneurial orientation, technology transfer and spinoff performance of U.S. universities. Research Policy, 34, 994-1009.

Pattnaik, P. N., \& Pandey, S. C. (2014). University Spinoffs: What, Why, and How? Technology Innovation Management Review, 4(12), 44-50.

Rasmussen, E., \& Borch, O.J. (2010). University capabilities in facilitating entrepreneurship: A longitudinal study of spin-off ventures at mid-range universities. Research Policy, 39, 602-612. 
Rasmussen, E., Mosey, S., \& Wright, M. (2014). The influence of university departments on the evolution of entrepreneurial competencies in spin-off ventures. Research Policy, 43, 92-106.

Shane, S., \& Stuart, T. (2002). Organizational endowments and the performance of university start-ups. Management Science, 48(1), 154-170.

Shane, S. (2004). Academic Entrepreneurship - University Spinoffs and Wealth Creation, Edward Elgar Publishing Limited, UK.

Siegel, D.S., Veugelers, R., \& Wright, M. (2007). Technology transfer offices and commercialization of university intellectual property: performance and policy implications. Oxford Review of Economic Policy, 23(4), 640-660.

Smilor, R., \& Matthews, J. (2004). University venturing: technology transfer and commercialisation in higher education. International Journal Technological Transfer Commercial, 3(1), 111-128

van Burg, E., Gilsing, V. A., Reymen, I. M. M. J., \& Romme, A. G. L. (2008). Creating university spin-offs: A science-based design perspective. The Journal of Product Innovation Management, 25(2), 114-128

Visintin, F., \& Pittino, D. (2014). Founding team composition and early performance of university-based spin-off companies. Technovation, 34, 31-43

Vohora, A., Wright, M., \& Lockett, A. (2004). Critical junctions in the development of university high-tech spinout companies. Research Policy, 33, 147-175.

\section{Other sources:}

Horizon 2020, The EU Framework Programme for Research and Innovation. Retrieved September 15, 2017, from http://ec.europa.eu/programmes/horizon2020/en

Development of legal framework for establishing the third mission of Serbian universities. Retrieved September 9, 2017, form http://www.if4tm.kg.ac.rs/

Cataloge on Research and Innovation Potential of University of Kragujevac. Retrieved September 15, 2017, from http://www.bsokg.kg.ac.rs/index.php?lang=en\&

Strategy on scientific and technological development of the Republic of Serbia for the period 2016-2020 - „Research for inovation“ („Official Gazete of the RS“ No. 25/2016). Retrieved August 18, 2017 from http://www.mpn.gov.rs/wp-content/uploads/2015/08/ Strategija-engleski-jezik.pdf

Strategy for development of education in Serbia to 2020 („Official Gazete of the RS“ No. 107/2012). Retrieved August 20, 2017 from http://www.mpn.gov.rs/wp-content/uploads/2015/08/STRATEGIJA-OBRAZOVANJA.pdf

Strategy for the support to development of small and medium-sized enterprises, entrepreneurship and competitiveness for the period from 2015 to 2020. („Official Gazete of the RS“ No. 55/05, 07/05 - 101/07, 65/08, 16/11, 68/12 -US, 72/12, 7/14 - US i 44/14). Retrieved August 18, 2017 from http://www.privreda.gov.rs/wp-content/uploads/2017/01/Strategija-I-Plan_eng_poslednje.pdf

Law on Innovation Activity („Official Gazette of the RS“ No. 110/05, 18/10 and 55/13). 